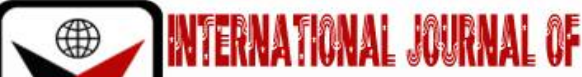

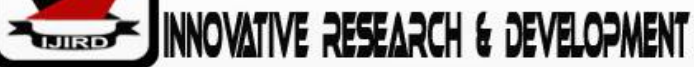

ISSN 2278 - 0211 (Online)

\section{Development of Halal Tourism in Indonesia: Halal Certification as a Top Priority and Awareness of Businessman}

\begin{tabular}{c} 
H.M.Yasir Nasution \\
Lecturer, Department of Sekolah Pasca Sarjana, \\
Universitas Islam Negeri Sumatera Utara, Indonesia \\
Hendri Tanjung \\
Tetty Yuliaty \\
Tecturer, Department of Sekolah Pasca Sarjana, Universitas Ibnu Kaldun, Indonesia \\
Lecturer, Department of Fakultas Ekonomi dan Bisnis, Universitas Sumatera Utara, Indonesia \\
\hline
\end{tabular}

\begin{abstract}
:
The concept of halal lifestyle, which now has an impact on the hospitality industry or the tourism industry, is increasingly becoming a trend in the world. The development of global phenomena of the world community which increasingly enjoys halal tourism has increased. Halal tourism which prioritizes the spiritual needs of tourists is apparently positively responded by many parties. Due to the increasing number of choices and the many needs of tourists, which certainly benefits the industry. Halal tourism does indeed promise better prospects in the future, the tourism industry is indeed able to accelerate economic growth and provide employment and also be able to drive the regional economy, the country and even the world. But unfortunately, the development of halal tourism in Indonesia is still experiencing many obstacles, especially the lack of concern for business people about products or services that have not been certified halal. Whereas with the most Muslim population in the world, this obligation should be very easy to implement, so that the development of halal tourism in Indonesia is able to exceed other countries. This research aims to find out what policy aspects are the most priority in implementing halal tourism in Indonesia; including; Halal certification, competency certification, guidelines for the implementation of halal and government supervision. The method used in this research is to conduct in-depth interviews. This research was conducted in several halal tourism locations that have been set by the Indonesian government such as West Nusa Tenggara, Aceh and North Sumatra, with speakers consisting of practitioners both tourism business practitioners, MUI, government and academics who indeed understand and do in the halal tourism industry originating from the three provinces in Indonesia. The results of this study indicate that the policy on halal certification is a priority aspect in the application of halal tourism in Indonesia, and needs to be a concern of the government considering the halal certification policy has not been firmly implemented so far.
\end{abstract}

Keywords: Halal lifestyle, halal tourism, policy, halal certification, aspects

\section{Introduction}

Halal tourism as one of Indonesia's great potentials attracts international attention, especially Indonesia has several times won international awards at the world halal tourism event, even having swept all awards in 2016. According to a source from Tempo.co.id (2016) it says " ... Indonesia is increasingly confident in developing halal tourism after successfully wiping out 12 of the 16 categories at the 2016 World Halal Tourism Award in Abu Dhabi, United Arab Emirates. " Meanwhile in 2019 Indonesia experienced a remarkable increase in the rating index rating of the Global Muslim Travel Index by occupying the number one position in the world and the holding of the Indonesia Muslim Travel Index to encourage increased halal tourism in Indonesia. With the growth of facilities, improvement in quality, and even support from a harmonious banking system, halal tourism in Indonesia will further enhance the attractiveness of tourist destinations and provide more comfort for potential Muslim tourists who are present. Chairman of the Indonesian Halal Tourism Association and CEO of SofyanCorp, Riyanto Sofyan (2019) said, "... the market for halal tourism has opened the eyes of the world to a huge economic potential.

As a target market, halal tourism is no longer a necessity for a limited circle. The demand for the concept of halal has developed very rapidly and this must be a major consideration in the development of tourism in Indonesia. Cultural diversity in Indonesia with its beautiful islands will always be an attraction for tourists to visit Indonesia.

With a very large Muslim population of around 1.8 billion of the world's population, the Muslim market potential is in line with the market potential in the People's Republic of China. In addition, the challenges of changing communication and transportation technology have changed many lifestyles in the world, tourism travel is now involving many young people and women as an important factor in world tourism style that must be able to be answered by halal 
tourism stakeholders.

Award after award that has been obtained from the WHTA international event, became a strong capital to encourage more vigorous promotion of halal tourism. The impact of stronger branding is expected to help boost the performance of the tourism industry, such as hotels for example. Proven hotel occupancy in Lombok from 55\% rose to around 80\% after winning the Best Halal Destination in 2015 "... So, the halal tourism industry growth of at least $20 \%$ will be achieved when winning the highest brand award event," according to the tourism minister at the time, Arif Yahya.

But unfortunately, the application of halal tourism in Indonesia is still not as developed as in other countries, some problems are still encountered in the implementation of halal tourism, one of which is the low awareness of businesses to certify halal products. According to Arief (2016) who was then the minister of tourism, this was because business people felt they had applied halal standards and had come from an Islamic country. Though every player in the tourism industry must have a standard that is recognized by the international tourism world, one of which is halal certification. The unpreparedness appeared because the government socialization related to halal products was not yet massive. Then, the SMEs do not pay attention to the knowledge of their employees about the requirements to get a halal certificate. Because halal certification is not just a certificate but how to apply the halal guarantee system within the company. Sapta said that in Malaysia halal certification has become a comparative advantage for producers to attract Muslim buyers and also to export

Likewise, the readiness of Indonesian human resources, in this case the government has issued a policy on competency certification and for tourism human resources this is absolutely applied in the context of preparing human resources with global competitiveness. According to Surono, the implementation of competency certification in tourism is carried out by the Professional Certification Agency (LSP) in the field of tourism, which is carried out during the process, learning outcomes or work experience results in the tourism business (2013). Certification in the field of tourism aims to provide recognition of labor competencies and at the same time improve the quality and competitiveness of the workforce. In the field of Tourism, what needs to be certified are hospitality, restaurants, travel service companies, and tour guides.

In a previous study by Sureerat Chookaew, Oraphan chanin, Jirapa Charatarawat, Pingpis Sriprasert, and Sudarat Nimpaya, (2015) with the title "Increasing Halal Tourism Potential at Andaman Gulf in the Gulf of Thailand for Muslim Country concluded that the initiative to develop Halal tourism or sharia tourism in Thailand is will focus on halal hotels, halal food and halal spas, services when Muslim tourists travel. Because of the demand from the Muslim market for halal services. Therefore, it is very important for Thailand to develop the concept of halal tourism business. Furthermore, halal tourism will directly meet the needs of Muslims, thus it will be one of the best products for the tourism industry in Thailand. Thailand's seriousness can certainly be a world barometer because so far Thailand is the country most frequently visited by tourists, with this country's interest in halal tourism, it should be a whip for Indonesia to develop halal tourism especially policies on the Guidelines for the Implementation of tourism based on sharia principles issued by DSN - MUI Number 108 / DSN-MUI / X / 2016 can be applied as a guide for halal tourism businesses.

Development of halal tourism also will not succeed without supervision, for that policy of halal tourism supervision, it is very necessary to have. The supervisory policy in this study refers to Perda No.2 Tahun 2016 West Nusa Tenggara regarding halal tourism. This Perda is important so that the implementation of halal tourism does not deviate from the established regulations, in accordance with the objectives. So that it will be easier for all parties to make halal tourism as one of the business sectors that can increase regional and state income which ultimately impacts the welfare of its people. With the largest Muslim population in the world, it is time for Indonesia to be the best example of halal tourism implementation, of course, if policies related to halal tourism are owned by the State and also stakeholders' awareness to comply.

\section{Literature Review}

\subsection{Halal Tourism}

Halal tourism is known in the literature in general to be equated with a number of terms such as Islamic tourism, sharia tourism, halal travel, halal friendly tourism destinations, Muslim-friendly travel destinations, halal lifestyle. President of the Islamic Nutrition Council of America, Muhammad Munir Caudry, explained that, "halal tourism is a new concept of tourism. Halal tourism is tourism that caters to holidays, by adjusting the vacation style to suit the needs and demands of a Muslim traveler. In this case hotels that carry the sharia principle do not serve alcoholic drinks and have separate swimming pools and spa facilities for men and women. Indonesia is familiar with sharia tourism since 2000 from the discussion of the OIC meeting. Sharia tourism is flexible, rational, simple and balanced tourism. Sharia tourism or halal tourism is one of the tourism systems intended for tourists, both for Muslim and non-Muslim tourists whose implementation complies with sharia rules. In Indonesia, Islamic tourism was introduced in 2012.

From the industry side, halal tourism is a complementary product and does not eliminate conventional types of tourism. This tourism aims to motivate tourists to get happiness and blessings from God. The purpose of halal tourism is to increase domestic and foreign tourist visits to visit various tourist destinations and attractions that have Islamic values, which are spread throughout Indonesia. Another aim is to encourage the growth and development of Islamic business in the tourism industry. It should be noted that tourism activities in Islam must be in accordance with generally accepted Islamic principles, namely halal. Islamic tourism or tourism in Islam focuses on issues such as involvement (Muslims), places (Islamic destinations), products (residential areas, food, and drinks), dimensions (economic, cultural, religious, etc.), and process management services (marketing and ethical issues).

Sharia Tourism considers the basic values of Muslims in its presentation ranging from accommodation, restaurants, to tourism activities that always refer to the norms of nature (Tourism Review, 2013) 


\subsection{Business Actors of Halal Tourism}

Tourism actors are all parties who play a role and are involved in tourism activities. As for the tourism actors according to Damanik and Weber are:

- Traveler; are consumers or users of products and services. Tourists have a variety of motives and backgrounds (interests, expectations, social characteristics, economic, cultural, etc.) that are different in conducting tourism activities.

- Tourism Industry / Service Provider; are all businesses that produce goods and services for tourism. They can be classified into two main groups, namely:

Direct Actors, namely tourism businesses that offer services directly to tourists or whose services are directly needed by tourists.

Indirect Players, namely businesses that specialize in products that indirectly support tourism.

Supporting Tourism Services; is a business that does not specifically offer tourism products and services but often relies on tourists as users of those services and products. This includes photography service providers, beauty services, fuel sales, and so on.

\subsection{Guidelines for the Provision of Tourism based on Sharia Principles}

Regulations or policies on halal tourism have not been owned by the Indonesian government until now, but DSN and MUI have made guidelines for the implementation of tourism based on sharia principles contained in the Fatwa of the National Sharia Council-Indonesian Ulema Council No: 108 / DSN-MUI (X) 2016 Concerning Guidelines for Sustainability Tourism. In the Halal Journal of LPPOM MUI, the parties in the organization of Sharia Tourism consist of tourists: Sharia Travel Bureau (BPWS): tourism entrepreneurs, sharia hotels, tour guides and therapies. There are 6 provisions related to the implementation of sharia tourism based on the National Sharia Board Fatwa Number 108 of 2016

\subsection{Halal Certification}

Halal certificate is a certificate issued by the Central or Provincial Ulema Council of Indonesia (MUI) regarding the halal of a food, beverage, medicines and cosmetics products produced by a company after being examined and declared halal by LPPOM MUI. The authority issuing halal product certification is the MUI which is technically handled by the Food, Drug and Cosmetics Assessment Institute (LPPOM). Halal Certification is a written fatwa of the Indonesian Ulema Council (MUI) which states the halal status of a product in accordance with Islamic law. This Halal Certificate is a requirement to put a halal label on product packaging. In implementing sharia tourism in Indonesia, which was launched in 2014, the Ministry of Tourism cooperated with the Indonesian Ulema Council (MUI) to determine halal standards for tourism products. MUI and Kemenpar guarantee, halal certification can not only be used by Muslim tourists. But even non-Muslim tourists can use it. In the RI Law No. 33 of 2014 concerning Guarantees of Halal Products consisting of 11 chapters and 68 articles, it has been explained that products that enter, circulate, and trade within the territory of Indonesia must be halalcertified. For this reason, the Government is responsible for organizing the Halal Product Guarantee (JPH). And will be subject to criminal sanctions in accordance with article 56 for Business Actors who do not maintain the halal status of Products that have obtained Halal Certificates. Unlawful halal law, required procedural regulations (al-hukm al-ijrai ').

\subsection{HR Competency Certification}

Increasing the human resources (HR) of the workforce needs to be increased to meet the competency test standards, as one of the requirements for workers who want to work in the tourism sector. The Chairperson of the National Professional Certificate Board (BNSP), Sumarna F. Abdurahman said the importance of competency will greatly affect labor competitiveness and product competitiveness in regional markets at the ASEAN level, as well as at the national level. Sumarna said, professional competency certification will also affect competition, it can be seen from the managers who already have competency certificates, herein lies the influence of competitiveness on products. Sumarna states, professional competency certification will also affect competition, can be seen from managers who already have certificates competence, herein lies the effect of competitiveness on the product. According to Sofyandi, Certification of Human Resources (HR) is an effort in implementing management functions and operational functions of human resources that are shown to increase the productive contribution of the organization's human resources towards the achievement of organizational goals effectively and efficiently.

\subsection{Development of Halal Tourism}

The development of the tourism sector in an area will directly or indirectly have an impact, both positive and negative impact pillars. Some sectors that can be affected by tourism activities include the economic, social and environmental sectors. Fandeli, argued that the development of tourism is basically the development of communities and regions that are based on

- Advancing the level of community life while preserving local identity and traditions.

- Increasing the level of income economically while distributing it evenly to the local population.

- Oriented to the development of small and medium scale tourism with large workforce absorption and oriented to cooperative technology.

\subsection{Problem Statement}

A quite serious problem in the development of halal tourism in Indonesia is halal tourism policies that do not yet exist except those issued by MUI and DSN, including the low awareness of businesses to certify halal products. Another 
problem also arises that is not yet ready for industry players in fulfilling the requirements to get halal certificates. Though every player in the tourism industry must have a standard that is recognized by the international tourism world. Likewise, the policies issued by the government have not been implemented seriously yet. For this reason, in order to develop halal tourism, and to contribute to the development of knowledge in this field, especially providing input to the government, this research needs to be carried out. This study provides the following questions:

- What is the reference in implementing halal tourism in Indonesia?

- How is the policy in the development of halal tourism in Indonesia so far?

- What aspects are the main priorities in the development of halal tourism in Indonesia?

\section{Methodology}

This research was conducted with a qualitative approach. Held in three regions that have carried out halal tourism in Indonesia namely West Nusa Tenggara, Aceh except North Sumatra as a comparison. West Nusa Tenggara Nusata and Aceh are two regions in Indonesia which are very popular in halal tourism and even West Nusa Tenggara has received many world-class awards as well as the Aceh region although not as much as West Nusa Tenggara. Consists of 12 expert speakers in the field of halal tourism. They are experts who have been in the halal tourism business or tourism business for quite a long time and are very understanding of halal tourism. There are 4 aspects of the policy under study, namely regarding the policy of competency certification issued by the government, halal certification by BPJPH and the Indonesian Ulema Council (MUI), guidance on the implementation of halal by the Indonesian Ulema Council (MUI) and halal tourism supervision.

The method of data collection is done through in-depth interview techniques both at the source's location and by telephone for confirmation of explanation. Miles and Huberman (Sugiyono, 2007) suggest that the activities in the qualitative data analysis are interactive and continue until the end, until the data is saturated. These activities are data reduction, data display and conclusion drawing / verification

\section{Results and Discussion}

\subsection{Results}

The results of interviews with resource persons consisting of business people were represented by hotel entrepreneurs in Indonesia, while the Indonesian Ulema Council was represented by officials at LPPOM MUI, now named BPJPH (Hlal Product Guarantee Agency, government represented by the relevant tourism office and the community including academics with a total of 12 people, all of whom come from the three regions studied, namely West Nusa Tenggara, Aceh and North Sumatra, all speakers agreed that Halal Certification is the most priority policy aspect in the development of halal tourism. Halal certification is very important In order to encourage the development of halal tourism, this study also found that policy regarding guidance on halal management was the second priority, while competency certification and supervision ranked third and fourth, and the results of this interview also found that the government's readiness to Developing halal tourism must be accompanied by halal tourism regulations which until now have not been owned by the government

\subsection{Discussion}

\subsubsection{Halal Certification Priority Policy in Development of Halal Tourism}

This research proves that all speakers from various regions studied, namely NTB, Aceh and North Sumatra agreed to state that the regions need a reference in the form of policies issued by the government in the development of halal tourism. Halal Certification Policy in developing halal tourism is the most important priority than any other policy. Although other policies in developing halal tourism are also very important, such as competency certification, guidance on the implementation of halal and supervision. Certification of Competence related to the quality and professionalism of HR has indeed been issued by the government, and specifically for actors in the tourism sector, this certification is quite important and mandatory.

Likewise, the guidance for halal management, which is issued by the MUI, has not been specified by many business players, while the supervision of halal tourism has only been owned by the Southeast Southeast Center through relevant regional governor regulations, and also the Aceh government through Qanun No.8/2013 on Tourism, and RI presidential regulation No, 63 of 2014 concerning Tourism supervision and control, although not specifically intended for halal tourism, this regulation is very much related to tourism implementation as well as Competency certification. The regulation on halal supervision has actually been stated in Perda No. 2 of 2016 West Nusa Tenggara regarding halal tourism whose scope of regulation includes destination, marketing and promotion, industry, institutional, guidance, supervision and financing.

So out of the three regions studied, West Nusa Tenggara is indeed the most prepared in the development of halal tourism, especially since it has had several times the world-level appreciation of halal tourism. But awareness in implementing halal certification is also still not very high, although the development is quite good. So that the government's seriousness in requiring halal certification and including halal certificates that meet the halal certification requirements for all food products from the Halal Product Guarantee Agency (BPJPH) under the Ministry of Religion, previously issued by the Indonesian Ulema Council (MUI). BPJPH officially operates on October 17, 2019. As mandated by Law Number 34 of 2014, concerning Halal Product Guarantee (JPH). 
But the firmness of the government still needs to be upheld because halal certification in Indonesia still has not shown significant signs of progress, moreover the speakers said that what left Indonesia behind in developing halal tourism with other countries was the consistency in applying halal certification for these business people. Other countries are very serious and must include halal labels in all their products, while in Indonesia they are still not aware of the importance of this halal certification, as stated by According to Tourism Minister Arief Yahya (2016) reveals that there are three obstacles faced by Indonesia in developing halal tourism, one of the most important is halal certification. According to Arief, that perception is the most dangerous in developing halal tourism, the development of halal tourism, Arief continued, business people do not want to be certified halal. The rejection was because they already felt that they had applied halal standards and had come from an Islamic state. Even though every tourism industry player must have a standard that is recognized by the international tourism world, one of which is there is halal certification, it is an absolute thing.

This research is in accordance with research from Muchaddam (2017). Although it has won several awards, and has had paying law to develop halal tourism, it does not mean that the NTB regional government does not face various challenges, among the challenges is to convince its citizens about the urgency of developing halal tourism in NTB, preparing competent human resources, and acceleration of halal certification for hotels, restaurants, small and medium industries (IKM) and micro small and medium enterprises (MSMEs), as well as synergies between stakeholders in the halal certification process for SMEs and MSMEs and halal tourism have not been supported by a set of laws and regulations that enable synergy between stakeholders in the halal certification process.

\section{Conclusions}

Government policies on halal tourism include: guidelines for the implementation of halal tourism, HR competency certification, halal certification and supervision are a reference in the application of halal tourism. The government policy especially halal certification is still an appeal at the time, until it became an obligation in October 2019. Even though it is an obligation, businesspersons are still not ready to fulfill the requirements for halal certification, due to the lack of information about halal certification for business people. This unpreparedness also appears because the government socialization related to halal products is not yet massive. Then, the SMEs do not pay attention to the knowledge of their employees about the requirements to get a halal certificate. Therefore inevitably business people must be prepared to carry out halal certification. Because the results of this study also prove that halal certification is the most priority policy in the development of halal tourism among several other policies. This policy is important because it is one of the worldrecognized standards in halal tourism, and absolutely for halal tourism business practitioners. Halal certification is now issued by the Halal Product Guarantee Agency (BPjJPH) under the Ministry of Religion, which was previously issued by the Indonesian Ulema Council (MUI). BPJPH officially operates on October 17, 2019. As mandated by Law Number 34 of 2014, concerning Halal Product Guarantee (JPH). The Indonesian Ulema Council (MUI) through the DSN MUI Fatwa Number 108 / DSN-MUI / X / 2016 has a local regulation on the implementation of halal tourism, which is now also one of the guidelines in the application of halal tourism in Indonesia.

\section{Recommendation}

In order for business people to be better prepared to do halal certification, education or socialization needs to be done as well as guidance for business people, so that the awareness of halal tourism businesses can be increased. Obligation of halal certification which has been imposed on October 17, 2019 ago, should be really serious and enforced for all business people in Indonesia, especially those engaged in the halal tourism business environment, although this obligation is for all business people. absolute world halal travel. Businesses who ignore these obligations need to be given clear sanctions or laws. The government should immediately issue a regulation on halal tourism which covers all scope. Businesses of halal tourism should comply with the requirements in the implementation and development of halal tourism, including equipping facilities for Muslim tourists and jointly oversee the implementation of halal tourism in their regions and other regions in Indonesia.

\section{References}

i. Muchaddam Fukham, (2017) Challenge of Developing Halal Tourism in Nusa Tenggara Barat, jurnal, dpr, go, id

ii. Damanik, Janianton dan Weber, Helmut (2006), Perencanaan Ekowisata dari teori ke aplikasi, Yogyakarta: PUSPAR UGM dan Andi,

iii. Gunn, Clare A, Tourism Planning. New York: Taylor and Francis, 1988

iv. Hamzah, (2019) PPHI Siap Dorong Pemerintah Demi Percepatan Wisata Halal, \#ISEF2019

v. https://www.gomuslim.co.id/read/news/2019/11/15/15933/-p-pphi-siap-dorong-pemerintah-demipercepatan-wisata-halal-p-.html (20 November 2019

vi. İqbal Musyaffa (17. October .2019), Kewajiban sertifikasi halal dorong peningkatan daya saing produk, Jakarta https://www.aa.com.tr/id/ekonomi/kewajiban-sertifikasi-halal-dorong-peningkatan-daya-saingproduk/1617188 (01 November 2019)

vii. Jurnal Halal, “Wisata Syariah, Sampai dimana?”, LPPOM MUI, No. 126 I Juli-Agustus TH. XX 2017.

viii. Kurniawan Gilang Widagdyo (2015) Analisis Pasar Pariwisata Halal di Indoensia, The Journal of Tauhidinomics Vol. 1 No. 1 (2015): 73-80

ix. Munirah, L., \& Ismail, H. N (2012), Muslim Tourists' Typologi in Malaysia: Perspectives and Challenges. Proceedings of the Tourism and Hospitality International Conference. Malaysia: Department of Urban and Regional Planning, Faculty of Built Environment. 
x. Pedoman Penyelenggaraan pariwisata berdasarkan prinsip syariah yang dikeluarkan oleh DSN- MUI Nomor 108/DSN-MUI/X/2016

xi. Perda No.2 Tahun 2016 Nusa Tenggara Barat tentang pariwisata halal

xii. Perda pemerintah Aceh, Qanun No.8 Tahun 2013 tentang Kepariwisataan

xiii. Sapta Nirwandar (1 October 2015), Penasihat Kehormatan Menteri Pariwisata: Potensi Wisata Syariah Kita Sangat, di download dari https://jonru.com pada bulan April 2016

xiv. Sugiyono, 2007, Metodologi Penelitian Bisnis, PT. Gramedia, Jakarta

xv. Sureerat Chookaew, Oraphan chanin, Jirapa Charatarawat, Pingpis Sriprasert, dan Sudarat Nimpaya, (2015) "Increasing Halal Tourism Potential at Andaman Gulf in Thailand for Muslim Country yang terbit dalam Journal of Economics, Business and Management, Vol.3 No.7

xvi. Surono, "Kebijakan Sertifikasi Profesi Pariwisata Nasional dakam Menghadapi AEC", diakses dari (http://webcache.googleusercontent.com), pada tanggal 24 April 2016, pukul 10.25)

xvii. Tempo.co (8 Desember 2016 2016) Indonesia Sapu Bersih 12 Penghargaan Wisata Halal Dunia. Jakarta

xviii. https://bisnis.tempo.co/read/826568/indonesia-sapu-bersih-12-penghargaan-wisata-halal-dunia/full\&view=ok: Aceh (

xix. Undang-undang Nomor 34 Tahun 2014, tentang Jaminan Produk Halal (JPH)

xx. Wuryasti, F, Wisata halal, konsep baru kegiatan wisata di Indonesia, Retrieved from, http://travel.detik.com/read/2013/10/30/152010/2399509/1382/, 2013 